\title{
Wide-Linear-Dynamic-Range Polymer Photodiode with a New BDT- Copolymer: The Role of Crystalline Orientation
}

\author{
Hyunki Ko, † Sungmin Park, ${ }^{\ddagger}$ Hae Jung Son*,‡ and Dae Sung Chung*,† \\ ${ }^{\dagger}$ Department of Energy Science and Engineering, Daegu Gyeongbuk Institute of Science and Technology (DGIST), \\ Daegu 42988, Republic of Korea \\ ‡Photo-electronic Hybrid Research Center, Korea Institute of Science and Technology, Seongbuk-Gu, Seoul 02792, \\ Republic of Korea
}

General: Unless otherwise stated, all of chemicals such as a reagent, catalyst, and solvent were purchased from Sigma Aldrich and used for the monomer and polymer synthesis without a further purification process. (4,8-Bis(4,5-didecylthiophen-2-yl)benzo[1,2b:4,5-b']dithiophene-2,6-diyl)bis(trimethylstannane) (1), 2,5-dibromo-3,4-difluorothiophene (2), and tributyl(3-octylthiophen-2yl)stannane (4) were synthesized according to similar procedures of literatures.[1-3] Nuclear magnetic resonance (NMR) was measured to confirm the chemical structure and purity of synthesized compounds using a Bruker Ascend 400 spectrometer in $\mathrm{CDCl}_{3}$ or $\mathrm{C}_{2} \mathrm{D}_{2} \mathrm{Cl}_{4}$ at $298 \mathrm{~K}$. Thermal decomposition temperature $\left(\mathrm{T}_{\mathrm{d}}\right)$ of polymers were determined by measuring thermogravimetric analysis (TGA, Q50 thermal analysis system) and decided at $5 \%$ weight loss. The molecular weight and distribution of polymers were measured by using a Waters gel-permeation chromatography system with chlorobenzene as an eluent at $60{ }^{\circ} \mathrm{C}$ and the system was calibrated with poly-styrene as narrow standards. 
<smiles>Fc1c(Br)sc(Br)c1F</smiles>

2<smiles>Fc1c(Br)sc(Br)c1F</smiles>

2

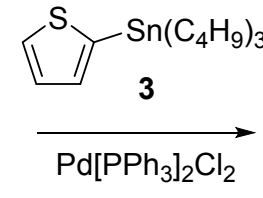

toluene, DMF

$80^{\circ} \mathrm{C}, 3 \mathrm{~h}$

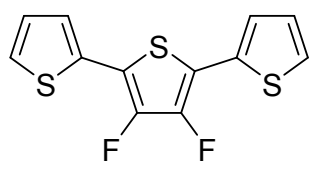

5

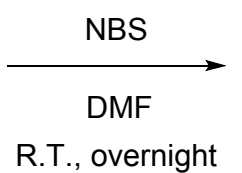

R.T., overnight

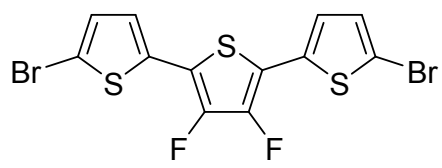

7

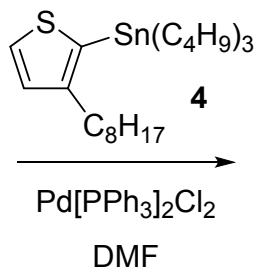

MW, $140^{\circ} \mathrm{C}, 10 \mathrm{~min}$

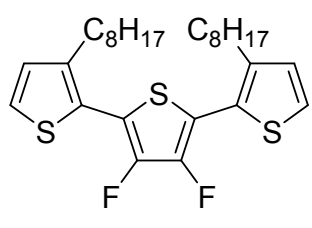

6

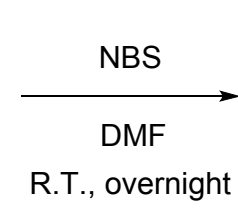

R.T., overnight

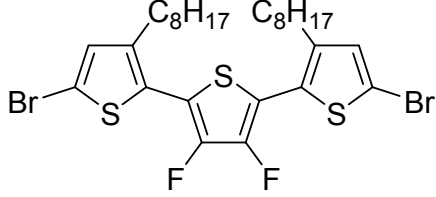

8

Scheme S1. Synthetic scheme of the monomers.

3',4'-difluoro-2,2':5',2"-terthiophene (5) 2,5-dibromo-3,4-difluorothiophene (2) (705 mg, 2.54 mmol), tributyl(thiophen-2yl)stannane (3) (2.84 g, $7.61 \mathrm{mmol})$, and bis(triphenylphosphine)palladium(II) dichloride $\left.\left(\mathrm{Pd}_{[} \mathrm{PPh}_{3}\right]_{2} \mathrm{Cl}_{2}\right)(89.1 \mathrm{mg}, 0.13 \mathrm{mmol})$ were put into a round-bottom reaction flask and dissolved in a solution of toluene ( $8 \mathrm{~mL})$ and DMF (2 mL). The flask was purged with argon flow and the reaction was performed at $80{ }^{\circ} \mathrm{C}$ for $3 \mathrm{~h}$ under argon protection. After the reaction, the crude compound was washed with water and extracted with ether. The organic fraction was dried by filter with anhydrous $\mathrm{MgSO}_{4}$ and concentrated by a rotary evaporator. The silica gel column chromatography was performed to purify and obtain the compound 5 (249 mg, $34.5 \%$ )

${ }^{1} \mathrm{H} \mathrm{NMR}\left(\mathrm{CDCl}_{3}, 400 \mathrm{MHz}\right) \delta(\mathrm{ppm}): 7.35(\mathrm{dd}, 2 \mathrm{H}), 7.27(\mathrm{dd}, 2 \mathrm{H}), 7.08(\mathrm{dd}, 2 \mathrm{H}) .{ }^{19} \mathrm{~F} \mathrm{NMR}\left(\mathrm{CDCl}_{3}, 376 \mathrm{MHz}\right) \delta(\mathrm{ppm}):-134.85$.

3',4'-difluoro-3,3"'-dioctyl-2,2':5',2"-terthiophene (6) 2,5-dibromo-3,4-difluorothiophene (2) (558.7 mg, 2.01 mmol), tributyl(3octylthiophen-2-yl)stannane (4) (2.44 g, $5.03 \mathrm{mmol})$, and $\mathrm{Pd}\left[\mathrm{PPh}_{3}\right]_{2} \mathrm{Cl}_{2}(28.2 \mathrm{mg}, 0.04 \mathrm{mmol})$ were put into a round-bottom reaction flask and dissolved in DMF (10 mL). The flask was purged with argon flow and the reaction was performed by microwave initiator at $140{ }^{\circ} \mathrm{C}$ for $10 \mathrm{~min}$ under argon protection. After the reaction, the crude compound was washed with water and extracted with ether. The organic fraction was dried by filter with anhydrous $\mathrm{MgSO}_{4}$ and concentrated by a rotary evaporator. The silica gel column chromatography was performed to purify and obtain the compound 6 (454.5 mg, $44.4 \%)$

${ }^{1} \mathrm{H} \mathrm{NMR}\left(\mathrm{CDCl}_{3}, 400 \mathrm{MHz}\right) \delta(\mathrm{ppm}): 7.32(\mathrm{~d}, 2 \mathrm{H}), 6.97(\mathrm{~d}, 2 \mathrm{H}), 2.69(\mathrm{t}, 4 \mathrm{H}), 1.62(\mathrm{~m}, 4 \mathrm{H}), 1.45-1.15(\mathrm{~m}, 20 \mathrm{H}), 0.95-0.78(\mathrm{t}, 6 \mathrm{H}) .{ }^{13} \mathrm{C}$ NMR $\left(\mathrm{CDCl}_{3}, 100 \mathrm{MHz}\right) \delta(\mathrm{ppm}): 142.57,141.43,129.51,126.34,124.06,113.1,31.97,30.65,29.59,29.49,29.35,22.76,14.17 .{ }^{19} \mathrm{~F}$ $\operatorname{NMR}\left(\mathrm{CDCl}_{3}, 376 \mathrm{MHz}\right) \delta(\mathrm{ppm}):-133.67$. 
5,5"-dibromo-3',4'-difluoro-2,2':5',2"-terthiophene (7) 3',4'-difluoro-2,2':5',2"'-terthiophene (5) (91.8 mg, $0.32 \mathrm{mmol}$ ) was put into a round-bottom reaction flask and dissolved in DMF (6.5 mL). $N$-Bromosuccinimide (NBS) (120.7 mg, $0.68 \mathrm{mmol})$ was added portionwise into the reaction flask wrapped with aluminum foil. The reaction was performed overnight at R.T. under dark condition. After the reaction, the crude compound was washed with water and extracted with ether. The organic fraction was dried by filter with anhydrous $\mathrm{MgSO}_{4}$ and concentrated by rotary evaporator. The silica gel column chromatography was performed to purify and obtain the compound 7 (97.4 $\mathrm{mg}, 68.2 \%)$

${ }^{1} \mathrm{H} \mathrm{NMR}\left(\mathrm{CDCl}_{3}, 400 \mathrm{MHz}\right) \delta(\mathrm{ppm}): 7.03(\mathrm{~d}, 2 \mathrm{H}), 6.99(\mathrm{~d}, 2 \mathrm{H}) \cdot{ }^{13} \mathrm{C} \mathrm{NMR}\left(\mathrm{CDCl}_{3}, 100 \mathrm{MHz}\right) \delta(\mathrm{ppm}): 141.13,132.78,130.46,125.06$, 113.40, 112.02. ${ }^{19} \mathrm{~F} \mathrm{NMR}\left(\mathrm{CDCl}_{3}, 376 \mathrm{MHz}\right) \delta(\mathrm{ppm}):-134.08$.

5,5"-dibromo-3',4'-difluoro-3,3"-dioctyl-2,2':5',2"-terthiophene (8): compound 8 was synthesized according to the similar procedure to that for compound 7, with 3',4'-difluoro-3,3"-dioctyl-2,2':5',2"'-terthiophene (6) (210 mg, $0.41 \mathrm{mmol}), \mathrm{DMF}(8.3 \mathrm{~mL})$, and NBS (161.6 mg, $0.91 \mathrm{mmol}) .(110.2 \mathrm{mg}, 40.1 \%)$.

${ }^{1} \mathrm{H} \mathrm{NMR}\left(\mathrm{CDCl}_{3}, 400 \mathrm{MHz}\right) \delta(\mathrm{ppm}): 6.93(\mathrm{~s}, 2 \mathrm{H}), 2.62(\mathrm{t}, 4 \mathrm{H}), 1.58(\mathrm{~m}, 4 \mathrm{H}), 1.38-1.16(\mathrm{~m}, 20 \mathrm{H}), 0.92-0.81(\mathrm{t}, 6 \mathrm{H}) .{ }^{13} \mathrm{C} \mathrm{NMR}\left(\mathrm{CDCl}{ }_{3}, 100\right.$ $\mathrm{MHz}) \delta(\mathrm{ppm}): 143.45,141.66,132.33,125.27,113.62,112.45,30.01,30.52,29.54,29.49,29.46,29.35,22.81,14.23 .{ }^{19} \mathrm{~F} \mathrm{NMR}^{\left(\mathrm{CDCl}_{3}\right.}$ $376 \mathrm{MHz}) \delta(\mathrm{ppm}):-132.65$.

\section{Synthesis of polymers}

BDT-Th-3T: (4,8-bis(4,5-didecylthiophen-2-yl)benzo[1,2-b:4,5-b']dithiophene-2,6-diyl)bis(trimethylstannane) (1) (248.2 mg, 0.2 mmol), 5,5"-dibromo-3',4'-difluoro-2,2':5',2"-terthiophene (7) (88.4 mg, $0.2 \mathrm{mmol}$ ), and tetrakis(triphenylphosphine)palladium(0) $\left(\mathrm{Pd}\left[\mathrm{PPh}_{3}\right]_{4}\right)(11.6 \mathrm{mg}, 10.0 \mu \mathrm{mol})$ were put into a round-bottom reaction flask and dissolved in a toluene $(4 \mathrm{~mL})$. The flask was purged with argon flow and the reaction was performed at $110^{\circ} \mathrm{C}$ for $48 \mathrm{~h}$ under argon protection. After the reaction, the crude polymer was precipitated in methaol and collected by a thimble filter. The polymer was purified by successive Soxhlet extraction with methanol, ethyl acetate, hexane, cyclohexane, and chloroform. The chloroform fraction was concentrated by a rotary evaporator and precipitated again in methanol. The precipitate was collected by PTFE filter and the polymer was completely dried under vacuum at $60{ }^{\circ} \mathrm{C} .(203 \mathrm{mg}, 84.9 \%)$

${ }^{1} \mathrm{H}$ NMR $\left(\mathrm{C}_{2} \mathrm{D}_{2} \mathrm{Cl}_{4}, 400 \mathrm{MHz}\right) \delta(\mathrm{ppm}):$ 7.90-6.45 (br, 8H), 3.20-2.35 (br, 8H), 2.05-0.10 (br, 76H). GPC: $\mathrm{M}_{\mathrm{n}}=82.4 \mathrm{~kg} / \mathrm{mol} ; \mathrm{PDI}=2.45$. 
BDT-Th-3AT: BDT-Th-3AT was synthesized according to the similar procedure to that for BDT-Th-3T, with $(4,8-\mathrm{bis}(4,5-$ didecylthiophen-2-yl)benzo[1,2-b:4,5-b']dithiophene-2,6-diyl)bis(trimethylstannane) (1) (168.5 mg, 0.136 mmol), 5,5"-dibromo3',4'-difluoro-3,3"-dioctyl-2,2':5',2"-terthiophene (8) (90.5 mg, 0.136 mmol), tetrakis(triphenylphosphine)palladium(0) $\left(\mathrm{Pd}\left[\mathrm{PPh}_{3}\right]_{4}\right)(7.8 \mathrm{mg}, 6.8 \mu \mathrm{mol})$, and toluene $(2.7 \mathrm{~mL}) .(188.5 \mathrm{mg}, 97.6 \%)$

${ }^{1} \mathrm{H}$ NMR $\left(\mathrm{C}_{2} \mathrm{D}_{2} \mathrm{Cl}_{4}, 400 \mathrm{MHz}\right) \delta(\mathrm{ppm}):$ 7.95-7.05 (br, 6H), 3.15-2.40 (br, 12H), 1.90-1.10 (br, 88H), 1.00-0.75 (br, 18H). GPC: $\mathrm{M}_{\mathrm{n}}=44.2$ $\mathrm{kg} / \mathrm{mol} ; \mathrm{PDI}=1.57$.

\section{Electrochemical properties}

Highest occupied molecular orbital (HOMO) energy level of polymers was estimated by measuring cyclic voltammetry (CV) with CH instruments electrochemical analyzer. A three-electrodes system was employed and consisted of a glassy carbon as a working electrode, a Pt wire as a counter electrode, and an $\mathrm{Ag} / \mathrm{AgCl}$ as a reference electrode. The polymer sample was prepared on working electrode by drop-casting. The electrolyte was used as a solution of tetrabutylammonium hexafluorophosphate in degassed acetonitrile $(0.1 \mathrm{M})$. The measurements were performed under argon protection and with a potential scan rate of $50 \mathrm{mV} \mathrm{s}^{-1}$. Ferrocene was also measured as an internal standard at same condition and ferrocene/ferroceium (Fc/Fc+) redox potential located at $0.51 \mathrm{eV}$ vs. $\mathrm{Ag} / \mathrm{AgCl}$ reference electrode was used for the calibration. HOMO energy level was calculated with following equation:

$\mathrm{E}_{\text {номо }}=-4.8-\left(\varphi_{\text {ох }}-0.51\right)(\mathrm{eV})$

where, $\varphi_{\text {ox }}$ is the onset oxidation potential of polymer from the measurement. 


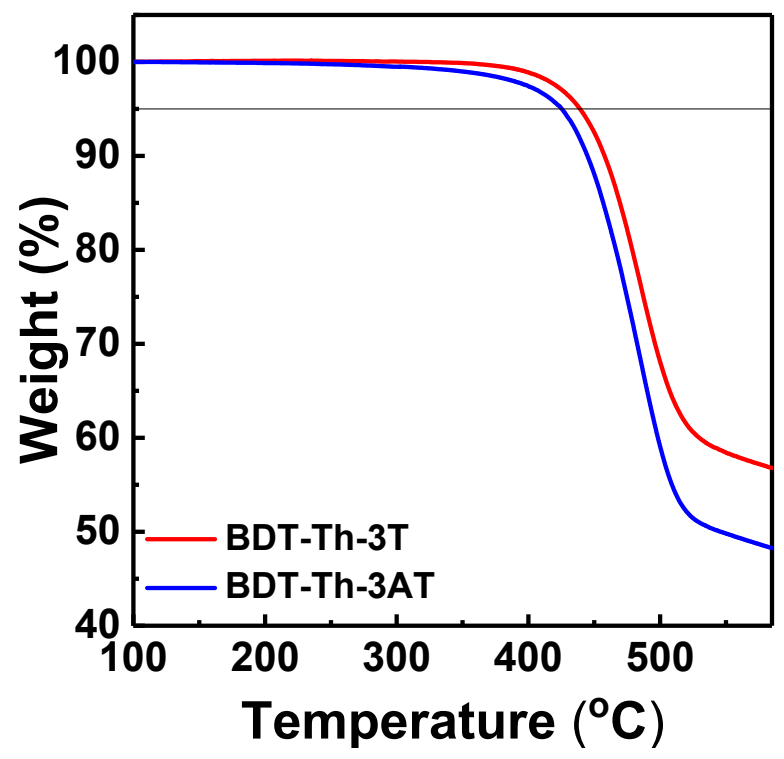

Figure S1. TGA curves of the polymers. 


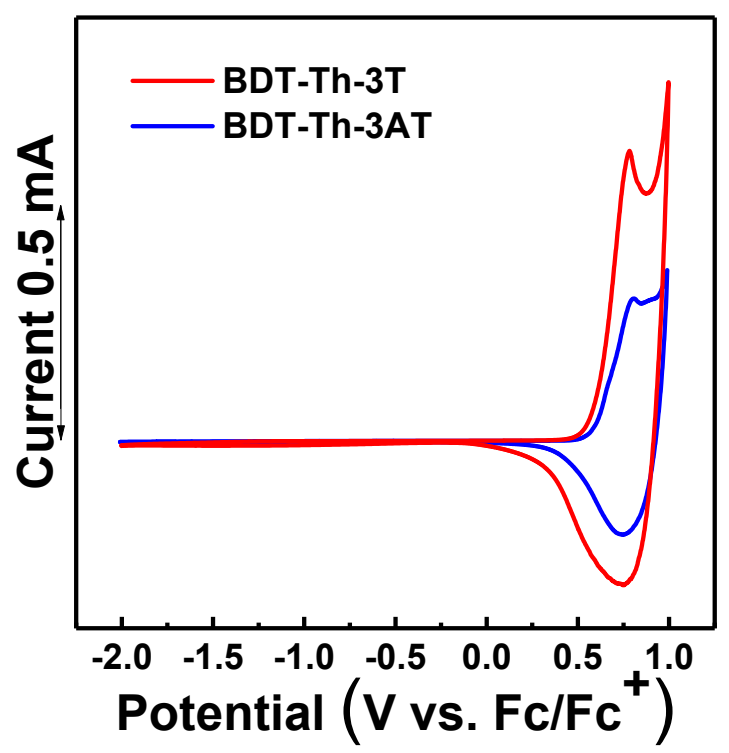

Figure S2. CV curve of the BDT-Th-3T and BDT-Th-3AT. 


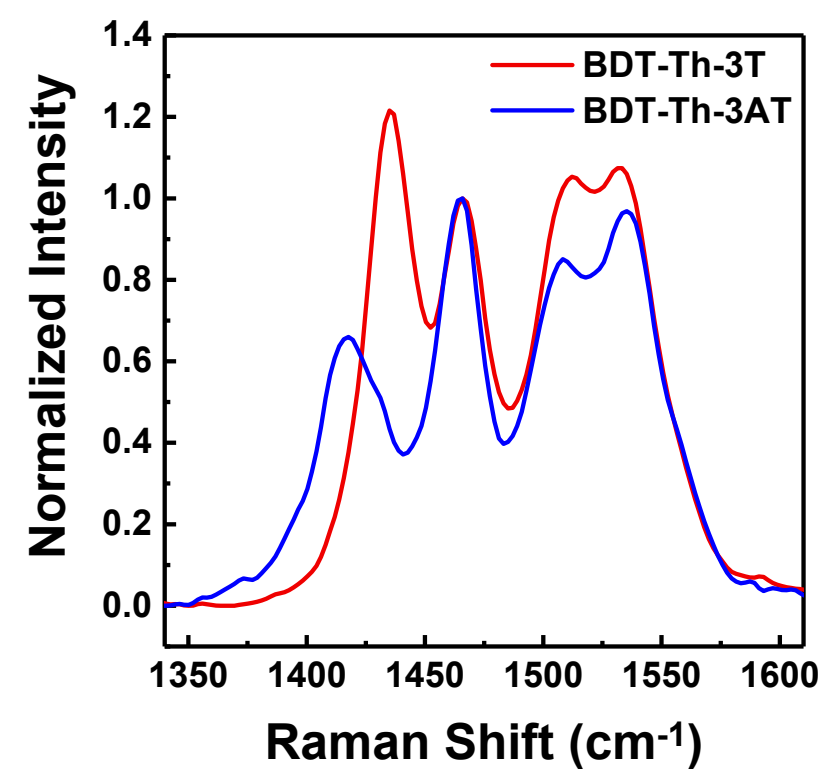

Figure S3. Comparison of Raman spectra for each polymer neat thin films. 

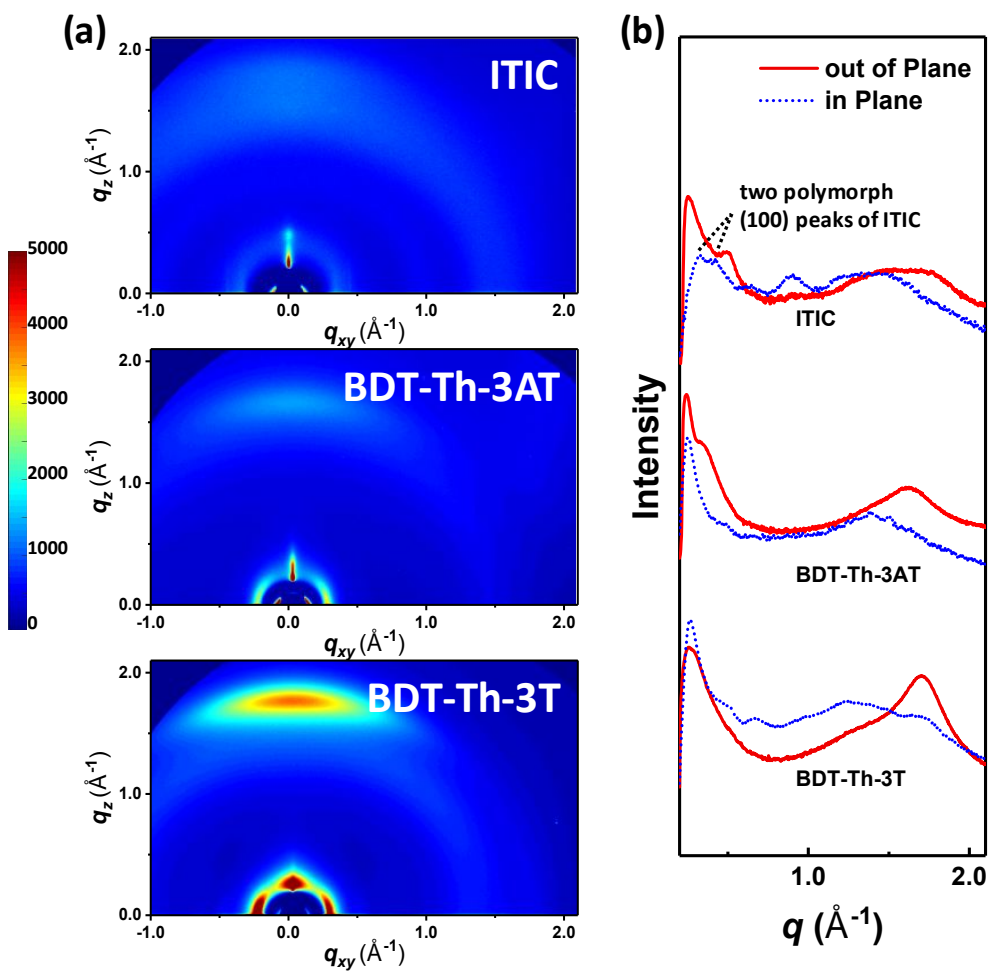

Figure S4. GIXD image and line cut for neat polymer films and ITIC. 
(a)

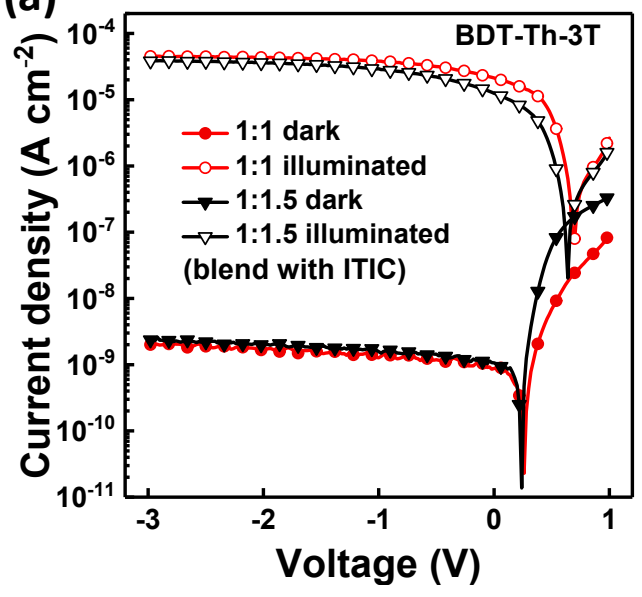

(b)

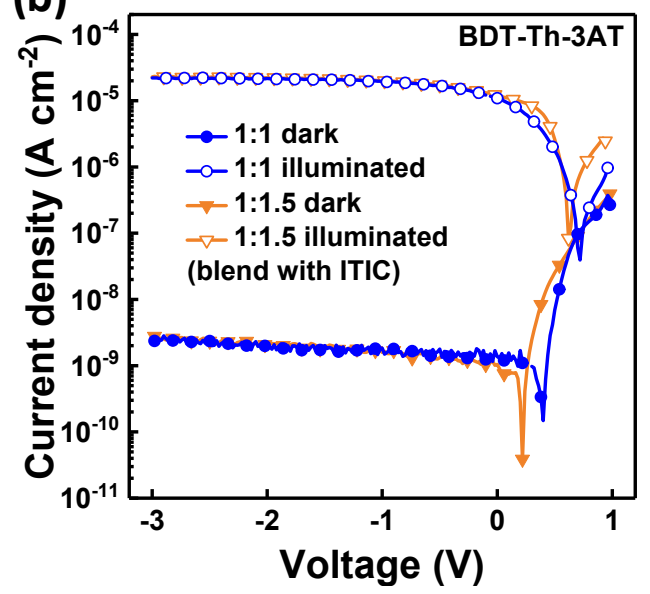

Figure S5. $J$ - $V$ characteristic of as-cast device. (a) BDT-Th-3T and (b) BDT-Th-3AT with ITIC, respectively. 

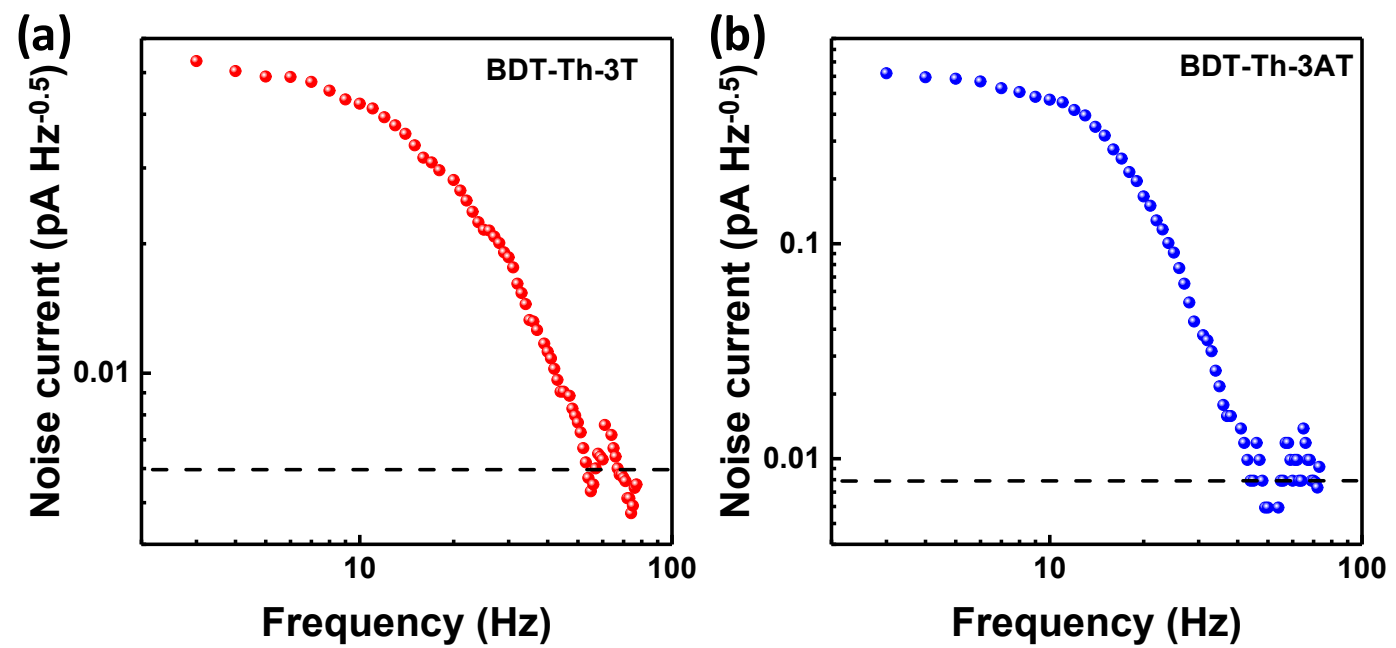

Figure S6. Noise current spectra of optimized device with (a) BDT-Th-3T (b) BDT-Th-3AT. 


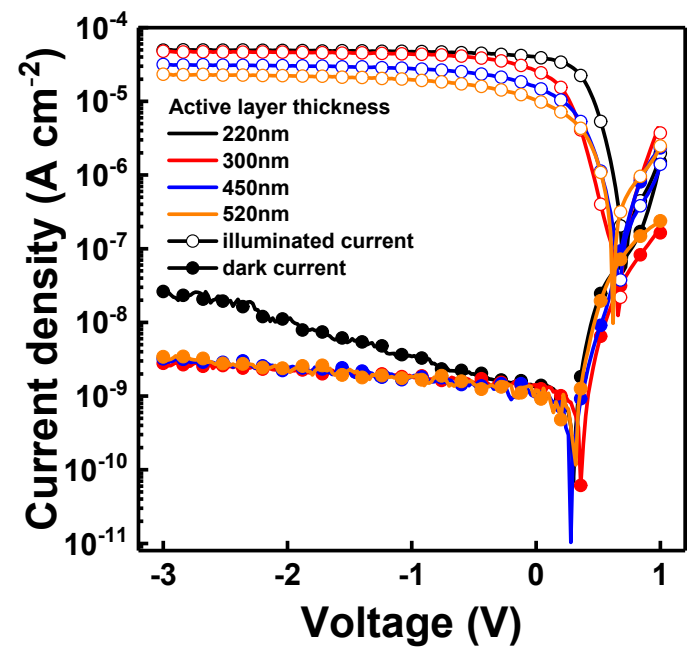

Figure S7. $J-V$ characteristics of the OPDs based on BDT-Th-3T:ITIC blend films for active layer thickness under the dark and illuminated $\left(620-\mathrm{nm}, 1.03 \times 10^{-4} \mathrm{~W} \mathrm{~cm}^{-2}\right)$ conditions. The devices were thermal annealed at $140^{\circ} \mathrm{C}$. 

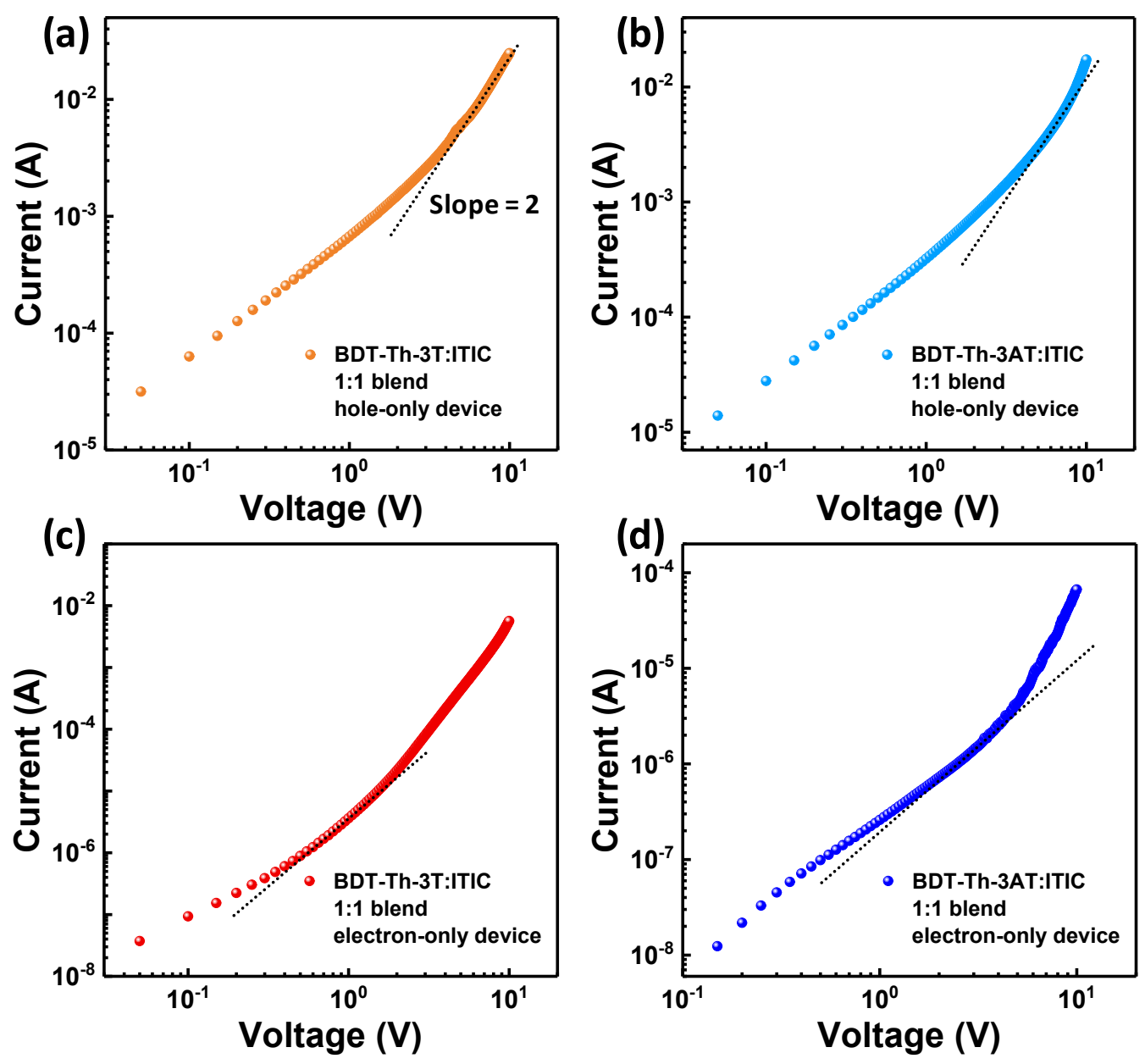

Figure S8. Dark $I-V$ characteristics of single-carrier devices based on BDT-Th-3T:ITIC and BDT-Th-3AT:ITIC BHJ films. Lines are fittings in the space-charge-limited current regime. The device structure of hole-only is ITO/PEDOT:PSS/BHJ/MoO $3 / \mathrm{Ag}^{\mathrm{P}} \mathrm{and}$ electrononly is ITO/PEIE/BHJ/LiF/Al. 
Table S1. UPS values for BDT-Th-3T and BDT-Th-3AT.

\begin{tabular}{|c|c|c|c|}
\hline polymer & cut-off & onset & homo level \\
\hline \hline BDT-Th-3T & 16.08 & 0.35 & 5.47 \\
\hline BDT-Th-3AT & 16.11 & 0.40 & 5.49 \\
\hline
\end{tabular}




\section{Referenece}

(1) Wang, M.; Hu, X.; Liu, P.; Li, W.; Gong, X.; Huang, F.; Cao, Y. Donor-Acceptor Conjugated Polymer Based on Naphtho[1,2-c:5,6c]bis[1,2,5]thiadiazole for High-Performance Polymer Solar Cells. J. Am. Chem. Soc. 2011, 133, 9638-9641

(2) Park, S.; Cho, J.; Ko, M. J.; Chung, D. S.; Son, H. J. Synthesis and Charge Transport Properties of Conjugated Polymers Incorporating Difluorothiophene as a Building Block. Macromolecules 2015, 48, 3883-3889

(3) Jeong, J.; Kumar, R. S.; Naveen, M.; Son, Y.-A.; Synthesis and characterization of triphenylaminebased polymers and their application towards solid-state electrochromic cells RSC Advances 2016, 6, 78984-78993. 